\title{
Productivity of Soybean on Different Agroecosystems
}

\author{
Dewi Rumbaina Mustikawati*, Nina Mulyanti, Ratna Wylis Arief
}

\author{
Lampung Assessment Institute for Agricultural Technology, Z.A. Pagar Alam street 1A, Rajabasa, Bandar Lampung, \\ Indonesia \\ *e-mail: rumbaina@yahoo.com
}

\begin{abstract}
This study aims to see the growth and productivity of soybeans in different agroecosystems. The study was conducted on paddy field located in Bumi Setia village, Seputih Mataram sub-district, Central Lampung district, and on dryland located in Mandah village, Natar sub-district, South Lampung district, Lampung Province, Indonesia, from April to July 2015. Soybean varieties grown at each location were Grobogan varieties. The variables observed were crop emergence, plant height at harvest, number of plant harvested, number of pods per plant, empty pods, weight of 100 grains, pod pests and productivity. Data were analyzed by $t$ test. The results showed that soybean productivity in dryland was $64.25 \%$ lower than productivity in paddy fields. The low yield of soybean varieties of Grobogan in dryland was caused due to drought factor when forming and filling pods. This can be seen from the decrease of weight of 100 grains of soybean seed in dryland up to $51.82 \%$ than in paddy field. The status of Grobogan varieties soybean vigor may change from large seed to medium seed if the water requirement is not optimum during the growing season.
\end{abstract}

Keywords - Soybean, agroecosystem, productivity, pod pest.

\section{INTRODUCTION}

Soybean is a food commodity source of vegetable protein is very important, especially for the population of Indonesia. In Indonesia, soybeans are consumed in the form of tofu and tempeh. Therefore, the biggest consumers are from industry of tofu and tempeh, then the next rank is feed industry, so the market potential of soybean in Indonesia is very wide and will continue to grow (Zakaria et al., 2010). Soybean has a wide use because it is highly nutritious and produces antioxidant substances (Krisdiana, 2007).

Grobogan varieties of soybeans released in 2008 with Decree of the Minister of Agriculture 238 / Kpts / SR.120 / $3 / 2008$. Grobogan varieties derived from the purification of the local population of Malabar Grobogan, with a yield potential of 3.40 tons/ha and the average yield of 2.77 tons/ha, the age of plants \pm 76 days, and seed weight \pm 18 g/100 grains (Kementerian Pertanian, 2013). This indicates that Grobogan varieties are large seeds.

The use of superior varieties is one of the important technological components in an effort to increase the production and productivity of soybeans. But efforts to increase production and productivity in soybean plant many obstacles, namely the existence of pests and diseases. Pod pests are one of the factors that can decrease soybean productivity. Loss of results due to this pod pests are the highest reaching 80-90\%, even puso if no control measures (Baliadi et al., 2008; Bedjo, 2011). The soybean pod pests are grouped into three types namely pod borer (Etiella sp.), Pod suckers (Nezara viridula), Piezodorus hybneri, Riptortus linearis), and pod eater (Helicoverpa armigera) (Baliadi et al., 2008; Marwoto \& Indiati, 2009; Naseri et al., 2010; Bae et al., 2014).

Symptoms of pest attack are varied, symptoms of pod borer attack if there are a hole in the skin of the former pod, the larvae into the seeds and damage the seeds by leaving the dirt from the borer (Tohamy \& El-Hafez, 2005), symptoms pod sucker attacks if the skin is wrinkled and there are a brown to black spots on the skin of the seeds (Bayu \& Tengkano, 2014), whereas the pod eater symptom seen to be a large hole in the pod where the seed is located or the pods are eaten, soybean pod pests leave no dirt in the pod (Malik, 2013), this distinguishes between the symptoms of Helicoverpa armigera attack with symptoms pod borer attack (Etiella $s p$.). One effort to anticipate the explosion of pest populations on soybean cultivation by cultivation technique can be done by planting soybean short age such as Grobogan varieties (Marwoto \& Indiati, 2009). The results showed that Grobogan varieties had secondary metabolite compounds that could inhibit or reduce the development of larvae and imago of $H$. armigera (Siahaan \& Redsway, 2014).

Soybean cultivation is cultivated on diverse agroecosystem conditions that affect the diversity of planting time (Zakaria et al., 2010). In Indonesia, the largest soybean area in paddy fields are about $60 \%$, which are planted after rice, the rest is grown on dryland. This condition shows that the area of soybean cultivation is 
mostly found in areas where infrastructure is relatively well established and relatively fertile than on dryland (Subandi, 2007). According to Atman (2006), paddy fields after paddy and dryland have the greatest potential for the development of soybean crops. However, according to Han (2006), soybean production in dryland agroecosystem is not maximal yet, increasing productivity tends to move slowly. This study aims to see the growth and productivity of Grobogan varieties of soybean in two different agroecosystems in Lampung, Indonesia.

\section{METHODOLOGY}

The study was conducted on two agroecosystems, namely paddy field and dryland. The paddy field was located in the village of Bumi Setia, Seputih Mataram Subdistrict, Central Lampung district, while the dryland was located in Mandah village, Natar subdistrict, South Lampung district, Lampung Province, Indonesia. The study starts from April to July 2015. On dryland the plant was fertilized with 75 $\mathrm{kg}$ of urea $+100 \mathrm{~kg} \mathrm{SP} 36+100 \mathrm{~kg} \mathrm{KCl}+1$ ton of organic fertilizer $+500 \mathrm{~kg}$ of dolomite per hectare, and in paddy field the plant was fertilized with $25 \mathrm{~kg}$ urea $+50 \mathrm{~kg}$ SP36 $+50 \mathrm{~kg} \mathrm{KCl}+1$ ton organic fertilizer per hectare. Aplication of organic fertilizers and dolomite when processing the soil 2 weeks before planting. Urea, Sp36 and $\mathrm{KCl}$ fertilizers were given when the plants were 7 days old. Plant spacing was $40 \mathrm{~cm} \times 15 \mathrm{~cm}, 2$ seeds per planting hole. The plots size of observation were $5 \mathrm{~m} \times 2 \mathrm{~m}$ randomly assigned, each location with 18 plots as replicates. Plants were sprayed insecticide biweekly until the plant was formed pods, and the treatment was the same between in paddy field with in dryland. The variables observed were crop emergence, plant height at harvest, number of harvested plants, number of pods per plant, empty pods, weight of 100 grains, pod pests by observing the attack symptoms on pods and seeds (each of 5 sample plants) and yield (conversion from tiles $5 \mathrm{~m} \times 2 \mathrm{~m}$ ). Data were analyzed by $t$ test. Intensity of pod pests attack were calculated by using formula:

$$
\mathrm{I}=\frac{\mathrm{a}}{\mathrm{a}+\mathrm{b}} \times 100 \%
$$

Table.1: Average component of plant growth in two agroecosystems.

\begin{tabular}{llll}
\hline Agroecosystem & Crop emergence $(\%)$ & Plant height $(\mathrm{cm})$ & $\begin{array}{l}\text { Number of harvested } \\
\text { plants }\end{array}$ \\
\hline Paddy land & 85.08 & 46.79 & 171.14 \\
Dryland & 82.60 & 47.52 & 181.14 \\
\hline
\end{tabular}

The numbers in the same column were not significantly different based on the $5 \%$ test.
$\mathrm{I}=$ Intensity of attack $(\%)$

$\mathrm{a}=$ Number of pods attacked

$\mathrm{b}=$ Number of healthy pods

\section{RESULTS AND DISCUSSION}

\subsection{Plant growth and productivity.}

The average of crop emergence, plant height and number of harvested plants in paddy fields and in dryland were not significantly different (Table 1). This shows the growth of homogeneous plants in the two agroecosystems. Crop emergence ranged from 82.6 to $85.08 \%$. Crop emergence indicates the state of seed quality before planting. If the seed quality is good then the crop emergence will be high. Factors affecting seed quality include genetic factors, environmental factors and seed status factors (physical and physiological condition of seeds). Genetic factors are innate factors associated with genetic composition of seeds. Environmental factors that affect the quality of seeds are related to conditions and treatments during preharvest, postharvest, and when marketing seeds. Physiological factors of seed are related to seed performance such as maturity level, degree of mechanical damage, level of obsolescence (relationship between initial vigor and duration stored), health level, size and density, chemical composition, structure and moisture content (Supriyadi, 2009; Admin, 2012). The seeds of soybeans in this study were good because of their growing $>80 \%$ (Harnowo et al., 2013).

The observation of the average height of the plants ranged from 46.79 to $47.52 \mathrm{~cm}$ (Table 1), which was slightly lower than that of the Grobogan varieties listed in the descriptions of 50-60 cm (Kementerian Pertanian, 2013). Grobogan varieties of crops grown in Limpok Regency of Aceh Besar were lower by $42.33 \mathrm{~cm}$ (Bakhtiar et al., 2014). Plant height of soybean are influenced by genetic factors, but may also be influenced by environmental factors (Han, 2006; Bakhtiar et al., 2014). 
The yield components such as number of pods, empty pods, productivity and weight of 100 soybean grains planted in paddy field were significantly different from those grown in dryland. Productivity of soybean of
Grobogan varieties were higher in paddy field than in dryland (Table 2). The number of pods per plant, the number of seeds per pod, and the size of the seeds directly affect the outcome (Hakim, 2012).

Table.2: Average yield components on two agroecosystems.

\begin{tabular}{lllll}
\hline Agroecosystem & $\begin{array}{l}\text { Number of pods per } \\
\text { plant }\end{array}$ & Empty pods $(\%)$ & $\begin{array}{l}\text { Productivity } \\
\text { (tons/ha) }\end{array}$ & $\begin{array}{l}\text { Weight of 100 } \\
\text { grains (grams) }\end{array}$ \\
\hline Paddy land & $39.42 *$ & $4.08 *$ & $2.07 *$ & $22.77 *$ \\
Dry land & 33.90 & 8.50 & 0.74 & 10.97 \\
\hline \multicolumn{2}{c}{ The numbers in the same column followed by * are significantly different based on the 5\% t test }
\end{tabular}

Planting soybeans at the right time will avoid from the constraints of drought or floods and interference of pests and diseases (Atman, 2006; Zakaria et al., 2010). In this activity soybeans were grown both in paddy field and in dryland in the late rain season. But in the paddy field due to planting on time so still get the optimum rainfall during its growth. While in the dryland due to planting rather late so that drought when flowering and filling pod, it can be seen from rainfall data in May-June at soybean location in dryland no rain at all (Table 3), whereas at that time plant of soybean at flowering phase and pod formation until filling of pods, so that this take effect on soybean yield components grown on dryland.

Drought or lack of water during the flowering phase can cause a decrease in the number of pods and seed size (Kari \& Nuralini, 1993 in Harsono et al., 2013; Suhartina et al., 2014). Drought stress inhibits the distribution of carbohydrates from the leaves to the pods so that the number and size of seeds decreases (Liu et al, 2004).

It was possible that the weight of 100 grains of Grobogan soybeans grown in dryland changed its status from large seeds to be medium seeds due to weight of 100 grains to
10.97 grams, while soybeans grown in paddy field have weight of 100 grains about 22.77 grams (Table 2), and this were higher than those listed in the description (Kementerian Pertanian, 2013). Soybean seeds are small if they weigh 8-10 grams/100 grains, classified as medium size if they weigh $>10-13$ grams $/ 100$ grains, and are considered large seeds if they weigh $>13$ grams $/ 100$ grains (Suharno \& Didik, 2008; Direktorat Jenderal Tanaman Pangan, 2013; Ginting \& Tastra, 2013). This indicates that the effect of drought during pod formation and filling of pods can decrease the weight of $51.82 \%$ soybean seeds. Farmer preference for seed size of soybean varies, some prefer large-seeded soybeans, some also want small or medium seeded soybeans. With the results of this study is expected farmers can consider about size seed of soybean that preferenced, because soybeans initially large seeds could have turned into a small seeds. The genetic properties of a variety may change due to environmental factors. Some components of environmental factors that are important in determining the growth and production of plants include solar radiation, temperature, soil, and water.

Table.3: The rainfall data in 2015.

\begin{tabular}{cllll}
\hline \multirow{2}{*}{ Months } & \multicolumn{3}{l}{ Paddy land } & \multicolumn{3}{l}{ Dryland } \\
\cline { 2 - 5 } & $\begin{array}{l}\text { Rainfall } \\
(\mathrm{mm})\end{array}$ & $\begin{array}{l}\text { Rainy day } \\
(\text { day })\end{array}$ & $\begin{array}{l}\text { Rainfall } \\
(\mathrm{mm})\end{array}$ & $\begin{array}{l}\text { Rainy day } \\
(\text { day })\end{array}$ \\
\hline March & 189 & 14 & 232.8 & 21 \\
April & 220 & 14 & 121 & 12 \\
May & 57 & 10 & 0 & 0 \\
June & 93 & 8 & 0 & 0 \\
\hline Total & 559 & 46 & 353.8 & 33 \\
Source: BPTP Lampung $;$ BPP Seputih Mataram,Central Lampung, Indonesia
\end{tabular}

Soybeans grown in paddy field experience optimum growth so that their productivity were also better than soybeans grown on dryland. Rainfall in paddy field was always present during soybean growth (Table 3).

The need water for soybean that harvested at 80-90 days ranges from $360-405 \mathrm{~mm}$ during its growth period, equivalent to $120-135 \mathrm{~mm}$ per month. Stadia soybean plants that are critical of water shortage are in the stadia start flowering until the end of flowering, then stadia of forming and filling pod, until pod maturation (Sumarno \& Ahmad, 2013). 
The productivity of soybean of Grobogan varieties that were grown on dryland due to drought was lower by $64.25 \%$ compared to Grobogan varieties grown in paddy field (Table 2). This was in line with the opinion of Adisarwanto (2010), the decrease of yield due to abiotic stress such as lack of water in soybean crops can reach 40$80 \%$. In addition, percentage of empty pods in soybeans grown on dryland were higher than soybeans grown in paddy field. The amount of empty pods can also decrease of yield.

\subsection{The attack of pod pests}

Identified pod pests seen from the symptoms of the attack were pod borer, pod suckers and pod eaters both in paddy field and in dryland. The pod sucking attacks in paddy field were not significantly different from those in dryland, whereas pod borer and pod-eaters in paddy field were significantly different from those in dryland and the intensity of their attacks were higher in soybean crops grown in paddy field. This indicates that the low productivity of soybean in dryland was not caused by pod pests attack, because pod pest incidence in paddy field such as pod borer and pod eaters were higher and significantly different than in dryland (Table 4). Low of soybean productivity in dryland was more caused by drought factor.

Table.4: Average of pod pests attack on soybean crops in two agroecosystems

\begin{tabular}{clll}
\hline Agroecosystem & Pod borer $(\%)$ & Pod suckers $(\%)$ & Pod eater $(\%)$ \\
\hline Paddy land & $6,37 *$ & 2,55 & $2,64 *$ \\
Dry land & 3,33 & 3,32 & 0,95 \\
\hline The numbers in the same column followed by * are significantly different based on the 5\% t test
\end{tabular}

The intensity of pest attacks on both agroecosystems were relatively low, ranging from $0.95-6.37 \%$ (Table 4), but they were included above the control threshold, except for pod-eaters in dryland below the control threshold. The control threshold of pod pests are if the damage of pods are $>2.50 \%$ (Baliadi et al., 2008). The extent of damage caused by pod pests on soybean crops are determined by various factors including high population, plant growth phase, plant response to pests, planted varieties and control measures (Bayu, 2015).

Increased pod pests incidence in the field are thought to be related to the extent of soybean cultivation and the availability of host plants continuously (Baliadi et al., 2008; Samosir et al., 2015). According to Marwoto and Indiati (2009), pest attacks will increase as water shortages and temperatures increase. However, in this study, pod borer attack and pod eaters attack were higher in paddy land than in dryland, except for pod sucking pests did look higher on dryland than in paddy field, but both were not significantly different (Table 4). The pest population dynamics in the field may be influenced by climatic and weather conditions, and the presence of host plants and natural enemies. Although in this study low soybean productivity in dryland was caused by drought factor, but the third pod pests both in paddy field and dryland have correlation to productivity with correlation

coefficient $r=1$, which means the attack of he third types of pod pests were very strong can decrease soybean productivity (Munir, 2008).

\section{CONCLUSION}

Productivity of soybean in dryland was lower $64,25 \%$ than productivity in paddy field. However, the low yield of soybean varieties Grobogan in dryland was caused more due to drought factor when forming and filling pods. This can be seen from the decrease of weight of 100 grains of soybean seed in dry land up to $51,82 \%$. The status of Grobogan varieties soybean vigor may change from large seed to medium seed if the water requirement is not optimum during the growing season. But pod pests too have a very strong correlation to decrease of yield with correlation coefficient $r=1$ both in paddy land as well in dryland.

\section{REFERENCES}

[1] Adisarwanto T. (2010). Strategi Peningkatan Produksi Kedelai Sebagai Upaya Untuk Memenuhi Kebutuhan di Dalam Negeri dan Mengurangi Impor. Pengembangan Inovasi Pertanian. Vol. 3 (4): 319331.

[2] Admin. (2012). Faktor Yang Mempengaruhi Mutu Benih. htp://smakita.net/faktor-yang-mempengaruhimutu-benih/

[3] Atman. (2006). Pengelolaan Tanaman Kedelai di Lahan Kering Masam. Jurnal Ilmiah Tambua. Vol. V (3). September-Desember: 281-287.

[4] Bae SD, Kim HJ, \& Mainali BP. (2014). Infestation of Riptortus pedestris (Fabricius) Decreases The Nutritional Quality and Germination Potensial of Soybean Seeds. J Asia-Pac Entomol 17: 477-481.

[5] Bakhtiar, Taufan H, Yadi J., \& Suwayda S. (2014). Keragaan Pertumbuhan dan Komponen Hasil Beberapa Varietas Unggul Kedelai di Aceh Besar. J. Floratek 9: 46-52.

[6] Baliadi Y, W Tengkano, \& Marwoto. (2008). Penggerek Polong Kedelai, Etiella Zinckenella 
Treitschke (Lepidoptera: Pyralidae) Dan Strategi Pengendaliannya di Indonesia. Jurnal Litbang Pertanian. 27 (4): 113-123.

[7] Bayu MSYI. (2015). Tingkat Serangan Berbagai Hama Polong Pada Plasma Nutfah Kedelai. PROS SEM NAS MASY BIODIV INDON. Vol. 1 (4) Juli: 878-883.

[8] Bayu MSYI \& W Tengkano. (2014). Endemik Kepik Hijau Pucat, Piezodorus hybneri Gmelin (Hemiptera: Pentatomidae) dan Pengendaliannya. Buletin Palawija 28: 73-83.

[9] Bedjo. (2011). Pengaruh konsentrasi HaNPV Terhadap Penekanan Populasi Hama Pemakan Polong Kedelai Helicoverpa armigera. Suara Perlindungan Tanaman 2 (2): p.10

[10] Direktorat Jenderal Tanaman Pangan. (2013). Pedoman Teknis Pengelolaan Produksi Kedelai. Kementerian Pertanian. 134p.

[11] Ginting E \& IK Tastra. (2013). Standar Mutu Biji Kedelai. Pp. 444-463 dalam Kedelai. Teknik Produksi dan Pengembangan. Badan Litbang Pertanian. Pusat Penelitian dan Pengembangan Tanaman Pangan.

[12] Hakim, L. (2012). Komponen Hasil dan Karakter Morfologi Penentu Hasil Kedelai. Penelitian Pertanian Tanaman Pangan. Vol. 31(3): 173-179.

[13] Han B. (2006). Uji Adaptif Beberapa Varietas Kedelai (Glycine $\max$ (L) (Merril) Pada Agroekosistem Lahan Kering Spesifik Lokasi Pada Musim Tanam Juni di Kebun Percobaan Lampineung Nanggroe Aceh Darussalam. J. Floratek Vol. 2: 7885.

[14] Harnowo D, J Rachman H, \& Suyamto. (2013). Kebutuhan dan Teknologi Produksi Benih Kedelai. Pp. 383-415 dalam Kedelai. Teknik Produksi dan Pengembangan. Badan Litbang Pertanian. Pusat Penelitian dan Pengembangan Tanaman Pangan.

[15] Harsono A, RD Purwaningrahayu, \& A Taufiq. (2013). Pengelolaan Air dan Drainase pada Budi Daya Kedelai. Pp. 253-280 in Kedelai. Teknik Produksi dan Pengembangan. Badan Litbang Pertanian. Pusat Penelitian dan Pengembangan Tanaman Pangan.

[16] Kementerian Pertanian. (2013). Deskripsi Varietas Unggul Kedelai. Badan Litbang Pertanian. Balai Penelitian Tanaman Aneka Kacang dan Umbi. 79p.

[17] Krisdiana R. (2007). Preferensi Industri Tahu dan Tempe Terhadap Ukuran dan Warna Biji Kedelai. Iptek Tanaman Pangan. Vol. 2 (1): 123-130.

[18] Liu F, CR Jensen, \& MN Anderson. (2004). Drought Stress Effect on Carbohydrate Concentration in Soybean Leaves and Pods During Early Reproductive
Development: its implication in altering pod set. Fild Crops Research 86: 1-13.

[19] Malik H. (2013). Hama Yang Sering Menyerang Tanaman Kedelai. http://simple420. blogspot. co.id/2013/01/

[20] Marwoto \& SW Indiati. (2009). Strategi Pengendalian Hama Kedelai Dalam Era Perubahan Iklim Global. Iptek Tanaman Pangan. Vol. 4 (1): 94103.

[21] Munir S. (2008). Statistik Deskriptif (1). Analisis Korelasi Product Moment. Fakultas Ekonomi Program Kelas Karyawan. Universitas Mercu Buana. $8 \mathrm{p}$.

[22] Naseri B, Fathipour Y, Moharramipour S, \& Hosseininaveh V. (2010). Nutritional Indices of The Cotton Bollworm, Helicoverpa armigera, on 13 Soybean Varieties. J. Insect Sci 10 (5): 1-14.

[23] Samosir S, Marheni, \& Syahrial O. (2015). Uji Preferensi Hama Kepik Hijau Nezara viridula L. (Hemiptera: Pentatomidae) Pada Tanaman Kacang Kedelai dan Kacang Panjang di Laboratorium. Jurnal Online Agroekoteaknologi Vol. 3 (2), Maret: 772778.

[24] Siahaan P \& Redsway DTM. (2014). Perkembangan Ulat Buah Heliotis armigera (Lepidoptera: Noctuidae) Pada Beberapa Varietas Kedelai (Glycine $\max$ L.). Jurnal Ilmiah Sains. Vol. 14 (1), April: 4651.

[25] Subandi. (2007). Kesiapan Teknologi Mendukung Peningkatan Produksi Menuju Swasembada Kedelai. Makalah Pada Simposium Tanaman Pangan V. Bogor, 28-29 Agustus 2007. Pusat Penelitian dan Pengembangan Tanaman Pangan. Bogor.

[26] Suharno \& Didik H. (2008). Karakteristik Biji Kedelai Untuk Produksi Tahu dan Tempe di Kendari, Sulawesi Tenggara. Buletin Teknologi dan Informasi Pertanian: 6-13.

[27] Suhartina, Purwantoro, Novita N, \& Abdullah T. (2014). Stabilitas Hasil Galur Kedelai Toleran Cekaman Kekeringan. Penelitian Pertanian Tanaman Pangan. Vol. 33 (1): 54-60.

[28] Sumarno \& Ahmad GM. (2013). Persyaratan Tumbuh dan Wilayah Produksi Kedelai di Indonesia. Pp. 74-103 dalam Kedelai. Teknik Produksi dan Pengembangan. Badan Litbang Pertanian. Pusat Penelitian dan Pengembangan Tanaman Pangan.

[29] Supriyadi H. (2009). Petunjuk Teknis Pengelolaan Tanaman dan Sumberdaya Terpadu (PTT) Kedelai. BPTP Jawa Barat. BBP2TP. Badan Litbang Pertanian. Departemen Pertanian. 14p.

[30] Tohamy HT \& El-Hafez GA. (2005). Integrated Crop Management System For Controlling Cowpea Pod Worm, Etiella zinckenella (Treit) in Relation To 
Soybean Yield at Minia and New Valley Regions. Egyptian J Agric Res 83: 1079-1098.

[31] Zakaria AK, Wahyuning KS, \& Reni K. (2010). Analisis Daya Saing Komoditas Kedelai Menurut Agro Ekosistem: Kasus Di Tiga Provinsi Di Indonesia. Jurnal Agro Ekonomi. Vol. 28 (1). Mei: 21-37. 